\title{
IMPLANTATION AND EARLY PREGNANCY IN THE AUTOTRANSPLANTED UTERUS OF THE GUINEA-PIG
}

\author{
K. P. BLAND \\ Department of Veterinary Physiology, \\ University of Edinburgh, Edinburgh EH9 1QH
}

(Received 2nd July 1971, accepted 18th August 1971)

It has frequently been suggested that the peripheral nervous system plays a part in the process of implantation and early pregnancy. Evidence for this was proposed by Nalbandov \& St. Clair (1958) but much of this evidence is now open to alternative explanations (Anderson, Bland \& Melampy, 1969). The study of implantation in a transplanted uterus would clarify the situation but attempts in the sheep have been unsuccessful (Niswender, Dziuk, Graber \& Kaltenbach, 1970). Transplantation of the uterus ensures complete isolation from its original nerve supply and any reinnervation is almost certainly nonspecific.

Two-stage uterine autotransplantation was performed in five guinea-pigs by the method described by Bland (1970). The first stage involved the severing of the broad ligament down the entire length of both uterine horns and then suturing the mesometrial aspect of the uterus to the muscle of the body wall. When the animal had returned normally to oestrus, at least twice, the final isolation of the uterus was performed by severing its tubal and cervical attachments. This second stage of the procedure was performed on the 6th day after mating when unimplanted blastocysts would be present in the uterus.

Three of the five animals failed to return to oestrus after the final operation and, at autopsy 28 to 31 days after mating, all three were found to be pregnant in the autotransplanted uterus. The other two guinea-pigs returned to heat after cycles of 21 and 22 days (see Table 1). These cycle lengths are in close agreement with those found in unmated animals after uterine autotransplantation (Bland, 1970). At autopsy, normal conceptuses were present in both horns in two of the pregnant animals (Guinea-pigs 19 and 26). The embryo in the third animal (Guinea-pig 69) was degenerating although the placenta was still histologically normal. Maintained corpora lutea were present in the ovaries of all three pregnant animals but had not enlarged above the maximum size found during the oestrous cycle. No degenerative changes were apparent in the luteal tissue and the vagina was fully mucified. In early pregnancy in the normal guinea-pig, the corpora lutea continue to enlarge until about the 20th day after mating, by which time they have attained a size of about $6 \mathrm{~mm}^{3}$ (range 5 to $7 \mathrm{~mm}^{3}$ ). This size is then maintained for the greater part of pregnancy. The reason for the absence of luteal enlargement in guinea-pigs pregnant in a transplanted uterus is unknown. 
TABLE 1

EFFEGT OF UTERINE TRANSPLANTATION AND PREGNANCY ON THE OESTROUS GYCLE AND GORPORA LUTEA OF GUINEA-PIGS

\begin{tabular}{|c|c|c|c|c|c|c|c|}
\hline \multirow{2}{*}{$\begin{array}{l}\text { Guinea-pig } \\
\text { no. }\end{array}$} & \multirow{2}{*}{$\begin{array}{c}\text { Control } \\
\text { cycle }\end{array}$} & \multirow{2}{*}{$\begin{array}{c}\text { Cycles between } \\
\text { operations }\end{array}$} & \multirow{2}{*}{$\begin{array}{l}\text { Mated } \\
\text { cycle }\end{array}$} & \multicolumn{2}{|c|}{ No. of conceptuses } & \multicolumn{2}{|c|}{$\begin{array}{l}\text { Mean size of maintained } \\
\text { corpora lutea }\left(\mathrm{mm}^{3}\right) \S\end{array}$} \\
\hline & & & & $\begin{array}{l}\text { Left } \\
\text { horn }\end{array}$ & $\begin{array}{l}\text { Right } \\
\text { horn }\end{array}$ & Left ovary & Right ovary \\
\hline $\begin{array}{l}66 \\
14 \\
69 \\
26 \\
19\end{array}$ & $\begin{array}{l}17 \\
17 \\
17 \\
15 \\
16\end{array}$ & $\begin{array}{l}18,18,14,16 \\
21,15 \\
17,18,16,17,14 \\
15,14,14 \\
17,18\end{array}$ & $\begin{array}{r}21 \\
22 \\
>31 \\
>28 \\
>30\end{array}$ & $\begin{array}{l}0 \\
0 \\
1 * \\
1 \\
3 \dagger\end{array}$ & $\begin{array}{l}0 \\
0 \\
0 \\
1 \\
1\end{array}$ & $\begin{array}{l}\text { - } \\
3 \cdot \overline{1}(3) \ddagger \\
3 \cdot 8(2) \\
1.9(2)\end{array}$ & $\begin{array}{l}\bar{Z} \\
2 \cdot \overline{7}(2) \\
3 \cdot 5(2) \\
2 \cdot 6(1)\end{array}$ \\
\hline
\end{tabular}

* Embryo degenerating but placenta normal.

† One of conceptuses was very small and consisted of placenta only.

$¥$ Numbers in parentheses are numbers of corpora lutea.

$\$$ Calculated by method of Rowlands (1956).

These findings indicate that in the guinea-pig an intact uterine nerve supply is not necessary for normal implantation and fetal development up to the 30th day of pregnancy. They also confirm a previous report (Bland, 1966) of successful implantation and placentation in a guinea-pig following the introduction of blastocysts (6-day) into a transplanted segment of uterus.

\section{REFERENGES}

Anderson, L. L., Bland, K. P. \& Melampy, R. M. (1969) Comparative aspects of uterine-luteal relationships. Recent Prog. Horm. Res. 25, 51.

BLAND, K. P. (1966) The role of the uterus in the control of the sexual cycle and implantation. Ph.D. thesis, London.

BLAND, K. P. (1970) Uterine autotransplantation to the abdominal wall in the guinea-pig. F. Endocr. 48,615 .

Nalbandov, A. V. \& St. Clair, L. E. (1958) Relation of the nervous system to implantation. Proceedings Third Symposium on Reproduction and Infertility, Colorado, pp. 83-87. Pergamon Press, London.

Niswender, G. D., Dziuk, P. J., Graber, J. \& Kaltenbach, C. C. (1970) Function of the corpus luteum in the ewe following relocation of the uterus or embryo. 7. Anim. Sci. 30, 935.

Rowlands, I. W. (1956) The corpus luteum of the guinea pig. Ciba Fdn Colloq. Ageing, 2, 69. 